\title{
PENINGKATAN HASIL BELAJAR IPS MELALUI IMPLEMENTASI CTL METODE GI BERBANTUAN MEDIA SMP NEGERI 6 RAHA
}

\author{
Jamrut, Aman \\ SMP Negeri 6 Raha, Universitas Negeri Yogyakarta \\ jamrut2002@yahoo.com,aman@uny.ac.id
}

\begin{abstract}
Abstrak
Penelitian ini bertujuan untuk (1) mengimplementasikan CTL dengan metode GI berbantuan media, (2) meningkatkan hasil belajar IPS. Subjek penelitian adalah 30 siswa kelas VIII-1 SMP Neg 6 Raha tahun pelajaran 2013/2014.Teknik pengumpulan data yang digunakan adalah observasi, tes, dan dokumentasi. Analisis data yang digunakan adalah deskriptif komparatif dengan nilai rata-rata untuk membandingkan kemajuan antar siklus. Hasil penelitian ini menunjukan bahwa implementasi CTL dengan metode GI berbantuan media meningkatan hasil belajar kognitif. Pada siklus I sebesar 69,33 atau mengalami ketuntasan belajar sebesar $60 \%$, menjadi 78,86 atau mengalami ketuntasan belajar sebesar $90 \%$ pada siklus II.
\end{abstract}

Kata Kunci: CTL, group investigation, media pembelajaran, hasil belajar

\section{IMPROVING LEARNING OUTCOME IN SOCIAL STUDIES THROUGHT THE IMPLEMENTATION OF CTL USING THE MEDIA-AIDED GROUP INVESTIGATION METHOD SMP NEGERI 6 RAHA}

\author{
Jamrut, Aman \\ SMP Negeri 6 Raha, Universitas Negeri Yogyakarta \\ jamrut2002@yahoo.com,aman@uny.ac.id
}

\begin{abstract}
This study aims to (1) implement the CTL using the media-aided group investigation method, (2) improve the learning IPS outcome. The subject is 30 students of class VIII-1 SMP Neg 3 Raha in 2013/2014. The data collection techniques used were observation, questionnaire, test, and documentation. The data analysis technique used was descriptive statistic using the mean value to compare the progress from cycle to cycle. The result is as follows an increace in learning outcome students'. In the first cycle 96.33 or the classical minimum passing grade criterion was $60 \%$ which became to 78.86 or the classical minimum passing grade criterion in the second cycle was $90 \%$.
\end{abstract}

Keywords: CTL, group investigation, instructional media, learning outcome 


\section{Pendahuluan}

Pembelajaran merupakan bagian yang memiliki peran sangat dominan untuk mewujudkan kualitas, baik proses maupun hasil (output) pendidikan. Pembelajaran juga memiliki pengaruh yang menyebabkan kualitas pendidikan menjadi rendah. Kualitas pembelajaran sangat tergantung dari kemampuan guru dalam melaksanakan proses pembelajaran. Pembelajaran yang dilaksanakan dengan baik dan tepat akan memberikan kontribusi yang baik pula bagi siswa, sebaliknya pembelajaran yang dilaksanakan dengan cara tidak baik akan menyebabkan potensi siswa sulit dikembangkan. Banyak fenomena negatif yang disebabkan secara langsung maupun tidak langsung oleh proses pembelajaran. Muchith, (2008, p.4) menyatakan bahwa hakikat pembelajaran adalah mengasah dan atau melatih moral kepribadian manusia, meskipun juga ada aspek fisiknya. Oleh karena itu, guru dituntut memiliki kemampuan dan sekaligus memiliki kepekaan dalam memahami fenomena, realitas dan potensi yang dimiliki oleh siswa.

Pendidikan IPS (social studies) merupakan salah satu mata pelajaran yang selalu berkembang sangat dinamis, karena pendidikan IPS adalah mempelajari hubungan perilaku masyarakat dengan lingkunganya yang pada dunia informasi dan globalisasi berkembang sangat dinamis. Oleh karena itu, pembelajaran IPS harus responsif terhadap tuntutan masyarakat modern.

Pendidikan IPS bertujuan membekali siswa dengan pengetahuan, sikap, dan keterampilan untuk menjadi warga masyarakat yang baik. Untuk dapat berpartisipasi menjadi warga negara yang baik maka perlu memiliki kemampuan yang berupa; pengetahuan (knowledge), keterampilan (skills), sikap dan nilai (attitudes and values), serta kemampuan berperilaku (action) (Sapriya, 2011, p.157). Untuk itu pembelajaran IPS harus dilaksanakan secara komprehensif menyangkut ranah kognitif, afektif, dan psikomotor siswa secara seimbang.

Pembelajaran IPS harus melibatkan siswa secara aktif dalam pembelajaran. Pembelajaran yang efektif harus mampu mendorong siswa untuk terlibat secara aktif dalam pembelajaran sehingga mendapatkan hasil yang maksimal. Dalam proses pembelajaran, siswa diarahkan mampu mengidentifikasi, merumuskan masalah, mencari dan menemukan fakta, menganalisis, menafsirkan, dan menarik kesimpulan. Untuk dapat mengembangkan kemampuan kognitif, siswa harus aktif mencari infomasi dari berbagai sumber, berdiskusi, dan menelaah dengan kritis informasi yang didapatkannya untuk membangun pengetahuannya sendiri. Untuk itu siswa perlu memiliki sikap yang baik terhadap pembelajaran. Dengan persepsi siswa yang baik terhadap pembelajaran, siswa akan menikmati belajar dalam suasana yang menyenangkan. Hal ini penting untuk meningkatkan aspek afektif dan mendorong keterlibatan siswa dalam aktivitas belajar. Kemampuan afektif akan berkembang jika siswa aktif melibatkan diri secara mental dalam pembelajaran. Kemampuan psikomotor siswa akan berkembang jika siswa aktif bergerak, berinteraksi dengan guru, siswa lainnya, serta dengan komponen pembelajaran lainnya.

Pembelajaran yang sesuai dengan karakteristik mata pelajaran IPS adalah pembelajaran yang menghubungkan siswa dengan kehidupan dunia nyata. Oleh karena itu, perlu kiranya mengimplementasikan Contextual Teaching and Learning (CTL) sebagai pembelajaran yang lebih memperhatikan potensi siswa, memperhatikan situasi dan kondisi lingkungan sekitar, memperhatikan sarana pembelajaran dan berpegang teguh pada tujuan pembelajaran yang ingin dicapai. Semua elemen dikemas dan dikelola oleh guru menjadi suasana yang menyenangkan, menggairahkan dan memberikan motivasi tinggi bagi siswa dalam belajar.

Contextual Teaching and Learning (CTL) didasarkan empat pilar pendidikan yang dicanangkan UNESCO, (1) Learning to do, maksudnya pembelajaran diupayakan untuk memberdayakan peserta didik agar mau/bersedia dan mampu memperkaya pengalaman belajarnya. (2) Learning to know, yaitu proses pembelajaran yang didesain dengan cara mengintensifkan interaksi dengan lingkungan baik lingkungan fisik, sosial dan budaya sehingga peserta didik mampu membangun pemahaman dan terhadap dunia di sekitarnya. (3) Learning to be, yaitu yang diharapkan siswa mampu membangun pengetahuan dan kepercayaan dirinya. Pengetahuan 
dan kepercayaan diri itu diperoleh setelah peserta didik aktif melakukan interaksi dengan lingkungan sekitarnya. (4) Learning to live together, yaitu pembelajaran yang lebih diarahakan upaya rnembentuk kepribadian untuk memahami dan mengenali keanekaragaman (kemajemukan) sehingga melahirkan sikap dan perilaku positif dalam merespon perbedaan atau keanekaragaman (Muchith, 2008, p.5).

Contextual Teaching and Learning (CTL) merupakan pendekatan pembelajaran yang mengaitkan konten mata pelajaran dengan situasi dunia nyata dan memotivasi siswa membuat hubungan antara pengetahuan dan penerapannya dalam kehidupan mereka sebagai warga masyarakat dan mampu memecahkan masalah. Contextual Teaching and Learning (CTL) ini merupakan pendekatan pembelajaran yang dapat memperkuat, memperluas dan menerapkan pengetahuan serta keterampilan akademik mereka dalam berbagai macam kondisi baik dilingkungan masyarakat maupun sekolah. Selain itu siswa dilatih untuk memecahkan masalah yang mereka hadapi/alami dalam suatu situasi atau simulasi sesuai dengan kondisi yang sebenarnya. Apabila pendekatan Contextual Teaching and Learning (CTL) dengan metode Group Investigation (GI) dengan bantuan media sebagai pengantar pesan diterapkan dengan benar, diharapkan siswa akan terlatih untuk dapat menghubungkan apa yang diperoleh di kelas dengan dunia nyata dalam kehidupan sehari-hari. Implementasi Contextual Teaching and Learning (CTL) metode Group Investigation (GI) merupakan inovasi strategi pembelajaran yang diharapkan dapat digunakan sebagai sarana untuk mengorganisasi dan melatih siswa memiliki sikap ilmiah, peka terhadap lingkungan serta memiliki keterampilan sosial atau kerjasama dalam kehidupan sehari-hari.

Penerapan metode Group Investigation membutuhkan media yang relevan dengan materi pembelajaran. Penggunaan media pembelajaran merupakan faktor yang sangat penting dalam pembelajaran IPS, karena pembelajaran akan lebih bermakna dan menyenangkan apabila siswa mengalami, melihat, dan mendengar langsung. Media berfungsi untuk mengkonkritkan materi pembelajaran yang bersifat abstrak. Semakin konkrit sumber belajar maka pembelajaran akan semakin bermakna bagi siswa.
Implementasi Contextual Teaching and Learning dengan metode Group Investigation (GI) berbantuan media lebih dimaksudkan kepada kemampuan guru dalam melaksanakan proses pembelajaran yang lebih mengedepankan idealitas pendidikan sehingga benar-benar akan menghasilkan kualitas pembelajaran yang efektif dan efisien. Idealitas pembelajaran yang dimaksud adalah melaksanakan proses pembelajaran yang lebih menitikberatkan pada upaya pemberdayaan siswa secara intelektual, sosial, dan budaya.

Berdasarkan hasil observasi yang dilakukan di kelas VIII-1 SMP Negeri 6 Raha Kabupaten Muna, Provinsi Sulawesi Tenggara banyak masalah yang ditemukan di antaranya: Siswa kurang tertarik dengan peajaran IPS yang bersifat teoritis dan bersifat hafalan. Pembelajaran IPS tidak menggunakan media pembelajaran. Pembelajaran IPS tidak menggunakan metode kooperatif. Hasil belajar siswa rendah hanya 20\% yang mencapai standar KKM. Aktifitas belajar siswa dalam proses pembelajaran tidak terorganisir. Metode dan gaya mengajar guru IPS kurang menarik. Guru belum menggunakan pendekatan Contextual Teaching and Learning (CTL). Guru belum optimal menumbuhkan sikap kritis, aktif dan santun. Proses belajar mengajar lebih banyak berpusat pada guru, murid hanya mencatat materi pelajaran. Siswa kurang semangat dalam mengikuti kegiatan pembelajaran. Pembelajaran IPS tidak memanfaatkan lingkungan alam sekitar sebagai media.

Kondisi ini tidak mampu dibaca oleh guru sehingga mengakibatkan pelajaran IPS menjadi sesuatu yang tidak berarti. Kadang-kadang guru IPS memiliki pandangan lain terhadap siswa, misalnya: "meskipun siswa diajar oleh malaikat tetap begitulah hasilnya". Guru yang profesional adalah guru yang mampu membaca situasi, memanfaatkan semua sumber belajar, menggunakan media pembelajaran, menggunakan model, metode, teknik maupun pendekatan pembelajaran yang kreatif, inovatif, bermakna dan menyenangkan.

Berdasarkan uraian latar belakang tersebut, maka peneliti sangat tertarik untuk melakukan Penelitian Tindakan Kelas (PTK) sebagai wujud tanggungjawab dari seorang guru profesional. 
Proses pembelajaran yang selama ini digunakan oleh guru terkesan monoton, kaku dan membosankan sehingga mengakibatkan kualitas pendidikan jalan ditempat. Oleh karena itu, perlu dilakukan terobosan dan menerapkan strategi pembelajaran yang modern agar proses pembelajaran menjadi bermakna, menyenangkan, yang bermuara pada peningkatan hasil belajar siswa. Tujuan penelitian ini adalah (1) untuk mengimplementasikan Contextual Teaching and Learning (CTL) dengan metode Group Investigation berbantuan media dan (2) untuk meingkatkan hasil belajar IPS siswa kelas VIII-1 di SMP Negeri 6 Raha Kabupaten Muna, Provinsi Sulawesi Tenggara.

\section{Metode Penelitian}

Metode penelitian yang digunakan adalah penelitian tindakan kelas model Kemmis \& Taggart. Prosedur penelitian tindakan kelas dilaksanakan secara siklus yang berlangsung secara berkesinambungan. Berdasarkan model Kemmis \& Taggart, langkah-langkah penelitian dilaksanakan dalam empat tahap yaitu: Perencanaan, Tindakan, Observasi, dan Refleksi.

\section{Perencanaan}

Tahap perencanaan berisi tentang perencanaan tindakan yang akan dilakukan. Rencana tindakan meliputi rencana pembelajaran, metode dan media yang akan digunakan dalam pembelajaran. Membuat instrumen/catatan lapangan yang akan digunakan untuk mengamati proses tindakan dan melihat hasil setelah dilakukan tindakan.

Pelaksanaan

Rencana tindakan yang sudah dibuat diimplementasikan dalam pembelajaran di kelas. Proses berlangsung di kelas dan pada jam pembelajaran yang sesuai dengan jadwal pelajaran yang berlaku.

Observasi

Observasi merupakan kegiatan mengamati yang bertujuan mendokumentasikan segala sesuatu berkaitan dengan pemberian tindakan yang dilakukan. Pelaksanaan observasi pada saat berlangsungnya tindakan. Observasi dilakukan dengan menggunakan lembaran kertas yang berfungsi sebagai catatan kejadian. Observasi dilakukan terhadap kegiatan peserta didik selama berlangsungnya kegiatan pembelajaran. Kegiatan observasi yang dilaksanakan pada waktu berlangsungnya kegiatan dapat bermanfaat untuk membetulkan apabila ada kegiatan yang kurang sesuai dengan rencana semula.

\section{Refleksi}

Refleksi merupakan kegiatan yang penting dalam penelitian karena dengan refleksi peneliti dapat melakukan evaluasi terhadap apa yang telah dilakukan. Tahap refleksi dilakukan untuk melakukan penilaian dan analisis terhadap proses yang terjadi, masalah yang muncul, dan segala hal yang berkaitan dengan tindakan yang telah dilakukan. Refleksi dilakukan untuk mengetahui apakah yang terjadi sesuai dengan rancangan, apakah tidak terjadi penyimpangan atau kesalahan prosedur, apakah prosesnya seperti yang dibayangkan dalam skenario (RPP), dan apakah hasilnya sudah memuaskan seperti yang diharapkan. Jika ternyata belum memuaskan dikarenakan sesuatu hal, maka perlu ada perencanaan ulang yang diperbaiki, dimodifikasi, dan jika perlu disusun skenario (RPP) baru.

Penelitian ini bertujuan untuk (1) mengimplementasikan CTL dengan metode GI berbantuan media dan (2) meningkatkan hasil belajar IPS pada siswa kelas VIII-1 semester I SMP Negeri Raha, Kabupaten Muna tahun pelajaran 2013/2014.

Penelitian ini mulai dilaksanakan pada bulan September sampai bulan Oktober 2013. Siswa kelas VIII-1 berjumlah 30 orang, yang terdiri dari 17 laki-laki dan 13 perempuan.

Teknik pengumpulan data pada penelitian ini dilakukan dengan pengamatan pada setiap situasi atau kejadian yang berkaitan dengan pelaksanaan penelitian. Hal tersebut dilakukan dengan tujuan untuk memperoleh data mengenai proses kegiatan pembelajaran. Teknik pengumpulan data hasil belajar siswa dilakukan dengan tes uji kompetensi yang dilakukan pada setiap akhir siklus penelitian tindakan. Secara spesifik pengumpulan data penelitian dilaksanakan dengan teknik sebagai berikut: (1) Observasi, tes hasil belajar, dokumentasi, dan catatan lapangan.

Analisis data yang digunakan adalah deskriptif komparatif dengan nilai rata-rata untuk membandingkan kemajuan antar siklus. 


\section{Hasil Penelitian dan Pembahasan}

Hasil Penelitian

Deskripsi Pelaksanaan Tindakan Siklus pertama

\section{Perencanaan}

Perencanaan dilaksanakan dengan mengacu pada data dan temuan-temuan yang diperoleh pada kegiatan observasi awal. Perencanan yang dilakukan meliputi berbagai macam langkah kegiatan. Sebelum menerapkan CTL dengan metode Group Investigation berbantuan media, terlebih dahulu peneliti mempersiapkan perangkat pendukung penelitian sebagai berikut: (1) Melakukan koordinasi dengan guru bidang studi IPS yang sudah ditunjuk oleh Kepala Sekolah dan berdiskusi tentang implementasi CTL dengan metode Group Investigation berbantuan media yang akan dilakukan pada saat pembelajaran. (2) Menyiapkan perangkat pembelajaran seperti: Silabus, Rencana Program Pembelajaran (RPP), angket, catatan lapangan, kisi-kisi tes uji kompetensi, soal uji kompetensi, dan kunci jawabannya. (3) Menyiapkan media powerpoint. (4) Menyiapkan alat pembelajaran seperti buku paket, laptop, dan LCD. (5) Menyiapkan instrumen pengumpulan data antara lain sebagai berikut. (a) daftar nama siswa kelas VIII-1, (b) lembar tes hasil belajar, (c) lembar rekaptulasi hasil belajar siswa, (d) lembar catatan lapangan

\section{Pelaksanaan Tindakan}

Pelaksanaan tindakan kelas pada siklus pertama dilaksanakan selama tiga kali pertemuan dan diakhiri dengan tes hasil belajar dan pengisian angket sikap. Pelaksanaan penelitian dilaksanakan pada hari Senin, 7 Oktober sampai Sabtu, 14 Oktober 2013 dengan Standar Kompetensi "Memahami Kegiatan Pelaku Ekonomi di Masyarakat" dan Kompetensi Dasar "Mendeskripsikan Pelaku Ekonomi Rumah Tangga, Masyarakat, Perusahaan, Koperasi dan Negara". Alokasi waktu yang dibutuhkan pada pelaksanaan tindakan siklus pertama sebanyak 6 x 40 menit atau tiga kali pertemuan yang dilaksanakan antara tanggal 7-14 Oktober 2013 dengan deskripsi setiap pertemuan sebagai berikut.

\section{Pertemuan Pertama}

Pertemuan pertama pada penelitian tindakan kelas dilaksanakan pada hari Senin, 7
Oktober 2013 waktu 2 x 40 menit (2 JP) dengan langkah-langkah sebagai berikut. (a) Tepat pukul 08.05 peneliti bersama kolaborator memasuki ruang kelas VIII-1 dengan mengucapkan salam. (b) Kolaborator mengecek keadaan siswa dan selanjutnya memimpin doa. (c) Sebelum pelajaran dimulai kolaborator memperkenalkan peneliti kepada siswa dengan tujuan agar siswa tidak merasa terganggu dengan keberadaan peneliti. d) Kolaborator mengawali pelajaran dengan menyampaikan bahwa kali ini cara belajar kita akan berbeda dengan sebelumnya. Hari ini guru akan menyampaikan materi menggunakan laptop dan LCD dan belajar secara berkelompokuntuk membahas masalah-masalah yang berkaitan dengan materi IPS yang dipelajari. (e) Kolaborator memberikan apersepsi tentang pelaku ekonomi. (f) Kolaborator menyampaikan tujuan pembelajaran yang akan dicapai. (g) Kolaborator menjelaskan langkah-langkah CTL dengan menggunakan metode Group Investigation. (h) Kolaborator bersama siswa mengidentifikasi topik yang akan dibahas dan membentuk kelompok secara heterogen, masing-masing kelompok berjumlah 6 orang. (i) Setelah kelompok terbentuk maka, siswa melakukan investigasi di perpustakaan dan di koperasi sekolah.

Kolaborator menyampaikan kepada siswa bahwa waktu tidak cukup untuk melanjutkan kegiatan pembelajaran. Pertemuan berikutnya akan dilanjutkan hari Sabtu, 12 Oktober 2013. Kolaborator mengakhiri pertemuan dengan berdoa bersama.

\section{Pertemuan Kedua}

Pertemuan kedua dilaksanakan pada hari Sabtu, 12 Oktober 2013 selama 2 x 40 menit (2 JP) dengan langkah-langkah sebagai berikut. (a) Pukul 07.05. Kolaborator bersama peneliti memasuki ruangan kelas VIII-1 sambil mengucapkan salam, mengecek keadaan siswa dan memimpin doa. (b) Kolaborator mengarahkan kelompok untuk melanjutkan investigasi di perpustakaan menggunakan literatur atau bukubuku IPS, Koran, majalah, dan berdiskusi salin bertukar pikiran. (c) Setelah membuat laporan masing-masing kelompok kembali di ruang kelas untuk menyajikan laporan hasil investigasi. (d) Kelompok mempresentasekan laporan hasil investigasi secara paralel. (e) Tepat pukul 
08.20 pertemuan kedua diakhiri. Kolaborator bersama siswa mengevaluasi proses penyajian laporan hasil investigasi, etika bertanya, dan etika menanggapi pertanyaan. (f) Kolaborator menyampaikan kepada siswa bahwa kegiatan pembelajaran akan dilanjutkan pada pertemuan selanjutnya yaitu hari Senin, 14 oktober 2013 dan akan diadakan tes hasil belajar, jenis tes pilihan ganda sebanyak 20 nomor serta mengisi angket. (g) Kolaborator menutup pertemuan dengan berdoa bersama.

\section{Pertemuan Ketiga}

Senin, 14 Oktober 2013 pukul 08.05, kolaborator bersama peneliti memasuki ruangan kelas VIII-1 dengan mengucapkan salam, mengecek keadaan siswa dan langsung memimpin doa. Kolaborator melaksanakan pembelajaran dengan langkah-langkah sebagai berikut. a) Kolaborator melakukan tes hasil belajar, waktu yang diberikan untuk mengerjakan tes yaitu 20 menit. Kolaborator menyampaikan kepada siswa bahwa, dalam mengerjakan tes siswa tidak diperbolehkan mencontek atau bekerjasama dengan orang lain. Jenis tes adalah pilihan ganda sebanyak 20 butir. b) Setelah tes selesai dikerjakan, dilanjutkan dengan pengisian lembar angket. Kemudian kolaborator, menutup pertemuan dengan berdoa bersama.

\section{Observasi}

Selama pelaksanaan pembelajaran peneliti melakukan observasi. Peneliti menemukan beberapa siswa kurang aktif dalam melaksanakan investigasi. Sebahagian siswa mengganggu temannya, bercerita dengan teman, dan keluar masuk dalam ruangan. Hal tersebut disebabkan karena kolaborator kurang meguasai pengelolaan kelas. Sejauh pengamatan peneliti siswa umumnya masih mengalami kesulitan menemukan jawaban dari permasalahan yang mereka investigasi. Saat diskusi kelompok berlangsung, siswa cukup aktif dan antusias. Siswa umumnya banyak bertanya, hanya ada beberapa siswa yang sibuk bercerita, mengganggu temannya, dan tertawa-tawa pada saat kelompok menyajikan laporan hasil investigasi. Sejauh pengamatan peneliti secara keseluruhan siswa umumnya mampu mengemukakan pendapat dan menanggapi laporan hasil investigasi kelompok lainnya.

\section{$\underline{\text { Refleksi }}$}

Pelaksanaan tindakan pada siklus pertama menerapkan langkah-langkah CTL dengan metode GI menggunakan media powerpoint dan perpustakaan. Media powerpoint digunakan untuk menampilkan gambar yang disesuaikan dengan materi yang dibahas, sedangkan penggunaan media perpustakaan bertujuan untuk memperdalam pengetahuan siswa tentang topik yang dibahas sesuai dengan permasalahan masing-masing kelompok dengan membaca buku, majalah, koran dan lain-lain yang relevan dengan materi. Penggunaan kedua media tersebut memiliki pengaruh positif terhadap minat, motivasi, dan hasil belajar siswa. Hal tersebut terlihat pada saat kelompok menyampaikan laporan hasil investigasi dan menyampaikan tanggapan. Pelaksanaan siklus pertama penggunaan kedua media tersebut belum meningkatkan hasil belajar IPS secara signifikan, sehingga diperlukan media tambahan yang akan digunakan pada siklus berikutnya.

\section{Peningkatan yang Terjadi dalam Tindakan Siklus}

Pertama sebagai berikut. a) Terjadi peningkatan hasil belajar siswa dibandingkan dengan kondisi awal. b) Terjadi peningkatan kualitas pembelajaran. Hal ini terlihat dengan penggunaan strategi CTL berbantuan media powerpoint tentang BUMN dan Koperasi menggunakan metode Group Investigation sehingga siswa merasa senang, nyaman dan merasakan masalah-masalah yang nyata sehingga mereka bisa menemukan sendiri jawabannya. c) Terjadi peningkatan aktivitas belajar, terlihat dari banyaknya pertanyaan terhadap kelompok yang meyampaikan laporan hasil investigasi.

\section{Kendala yang Dihadapi Pada Penelitian Siklus} Pertama

Pelaksanaan penelitian tindakan pada siklus pertama mengalami kendala sebagai berikut. a) Arus listrik tiba-tiba padam pada saat melaksanakan pembelajaran, sehingga menimbulkan kegaduhan dalam kelas. b) Kolaborator masih belum menjalankan komponen CTL dan langkah-langkah Group Ivestigation secara maksimal karena belum memahami secara menyeluruh konsep tersebut. c) Kurangnya sumber belajar yang tersedia, sehingga tidak semua kelompok melakukan 
investigasi secara maksimal. d) Siswa belum memahami secara komprehensif prosedur investigasi, sehingga kolaborator banyak menghabiskan e) Waktu untuk menjelaskannya. f) Aktivitas siswa pada saat menanggapi hasil investigasi kelompok cenderung gaduh hal ini disebabkan oleh kemampuan kolaborator mengelola kelas belum maksimal. g) Kolaborator sering meninggalkan ruang keles VIII-1, karena mengurusi gaji guru-guru SMP Negeri 6 Raha.

\section{Alternatif Tindakan Pada Siklus Kedua}

Berdasarkan temuan-temuan pada siklus pertama, peneliti bersama kolaborator menyusun strategi tindakan pada siklus kedua, antara lain. a) Mempersiapkan genset sebagai pengganti arus listrik dari PLN. b) Kolaborator harus lebih meguasai komponen CTL dan langkah-langkah metode Group Investigation. c) Kolaborator dan peneliti mencari solusi menyediakan sumber belajar agar CTL lebih bermakna dan benarbenar dirasakan secara nyata oleh siswa. d) Mengontrol siswa pada saat menyajikan dan menanggapi laporan hasil investigasi kelompok. e) Menggunakan pasar sebagai media dan melakukan pengamatan secara langsung. Peneliti dan kolaborator mendampingi siswa pada saat melaksanakan investigasi di lapangan.

\section{Hasil Belajar Siklus Pertama}

Data hasil belajar penelitian siklus pertama diperoleh dari pelaksanaan tes uji kompetensi yang dilaksanakan pada pertemuan ketiga hari Senin, 14 Oktober 2013. Pelaksanaan tes uji kompetensi siklus pertama diikuti oleh 30 orang siswa dan dilaksanakan selama 1 jam pelajaran. Jumlah butir soal yang diujikan sebanyak 20 butir dengan jenis soal pilihan ganda.

Berdasarkan hasil tes uji kompetensi yang dilakukan pada siklus pertama diperoleh data nilai hasil belajar siswa dengan rincian sebagai berikut.

Tabel 1. Rincian hasil belajar ranah kognitif siklus pertama

\begin{tabular}{llcc}
\hline No & Rincian hasil belajar & Jah & Persentase \\
\hline 1 & Nilai rata-rata & 69.33 & - \\
2 & Tuntas & 12 & $40 \%$ \\
3 & Belum tuntas & 18 & $60 \%$ \\
Ketercapaian & & Belum \\
\hline
\end{tabular}

Berdasarkan data tersebut nilai rata-rata siswa sebesar 69.33, siswa yang tuntas belajar sebanyak 12 orang dan yang tidak tuntas sebanyak 18 orang

\section{Deskripsi Pelaksanan Tindakan Siklus Kedua}

Penelitian tindakan kelas pada siklus kedua dilaksanakan sebanyak 3 (tiga) kali pertemuan. Pelaksanaan penelitian ini dilaksanakn pada hari Sabtu, 19 Oktober 2013 sampai Sabtu, 26 Oktober 2013. Prosedur pelaksanaan tindakan kelas sikus kedua meliputi empat tahapan yaitu perencanaan, pelaksanaan tindakan, observasi, dan refleksi. Secara spesifik empat tahapan penelitian tersebut dideskripsikan sebagai berikut.

\section{Perencanaan}

Tahapan perencanaan yang dilakukan pada siklus kedua mengacu pada alternatif tindakan dan solusi yang dirumuskan peneliti dan kolaborator pada tahapan refleksi pada siklus pertama. Langkah-langkah yang dilaksanakan pada siklus kedua yaitu kegiatan perencanaan dilaksanakan dengan mengacu pada data dan temuan-temuan yang diperoleh dalam kegiatan refleksi pada siklus pertama, perencanan yang dilakukan meliputi berbagai macam langkah kegiatan sebelum dilakukan tindakan CTL bebantuan media powerpoint dan lingkungan pasar menggunakan metode Group Investigation dengan mempersiapkan perangkat pendukung penelitian sebagai berikut. 1) Melakukan koordinasi dengan kolaborator dan meminta izin kepada Kepala Sekolah untuk melakukan kunjungan lapangan sebagai implementasi CTL menggunakan metode group investigation. Menyiapkan perangkat pembelajaran seperti: silabus, Rencana Program Pembelajaran (RPP), angket, kisi-kisi tes uji komptensi, soal uji kompetensi, dan kunci jawabannya. 2) Menyiapkan media dan alat pembelajaran seperti powerpoit buku paket, laptop, LCD, Genset. 3) Menyiapkan instrumen pengumpulan data antara lain. a) daftar nama siswa kelas VIII-1. b) lembar rekaptulasi hasil belajar siswa. c) lembar tes hasil belajar. d) lembar catatan lapangan

\section{Pelaksanaan Tindakan}

Pelaksanaan Penelitian Tindakan Kelas pada siklus kedua membahas Standar Komptensi "Memahami Kegiatan Pelaku di Masyarakat" dengan Komptensi Dasar "Mengidentifikasi bentuk pasar dalam kegiatan ekonomi masyarakat" 
dengan deskripsi setiap pertemuan sebagai berikut.

\section{Pertemuan Pertama}

Pertemuan pertama pada penelitian tindakan kelas dilaksanakan pada hari Sabtu, 19 Oktober 2013 dengan langkah-langkah pembelajaran sebagai berikut. 1) Tepat pukul 07.05 peneliti bersama kolaborator memasuki ruang kelas VIII-1 dengan mengucapkan salam. 2) Kolaborator menyiapkan alat pembelajaran (laptop, dan LCD projector). 3) Kolaborator mengecek keadaan siswa dan selanjutnya memimpin doa. 4) Kolaborator memberikan apersepsi tentang pasar dan menyampaikan tujuan pembelajaran yang akan dicapai. 5) Kolaborator menjelaskan langkah-langkah metode Group Investigation. 6) Kolaborator bersama siswa mengidentifikasi topik yang akan dibahas dan membentuk kelompok secara heterogen, masing-masing kelompok berjumlah 6 orang. 7) Kelompok melakukan investigasi di perpustakaan dengan membaca buku-buku pelajaran IPS, koran, majalah, dan referensi yang terkait dengan materi dan dilajutkan dengan mengunjungi pasar kecamatan Lohia untuk melakukan observasi. 8) Kolaborator menyampaikan agar pelajaran IPS materi "Pasar" benar-benar kontekstual maka siswa melakukan kunjungan lapangan (observasi) di Pasar Kecamatan Lohia. Kunjungan tersebut dilaksanakan pada hari Minggu, 20 Oktober 2013. 9) Pukul 08.55 pelajaran diakhiri dengan berdoa bersama.

\section{Pertemuan Kedua}

Pertemuan kedua dilaksanakan pada hari Senin, 22 Oktober 2013 dengan langkah-langkah sebagai berikut. 1) Tepat pukul 08.05 kolaborator dan peneliti memasuki ruangan dengan bersalam, mengecek keadaan siswa dan memimpin doa. 2) Kolaborator bertanya apakah sudah melakukan investiagsi di Pasar Kecamatan Lohia? Selanjutnya kolaborator mempersilahkan kelompok untuk mempresentasikan laporannya secara paralel dan dimulai dari kelompok 1, 2, 3, 4 dan 5, waktu yang akan digunakan adalah 60 menit. 3) Kolaborator bersama siswa menyimpulkan hasil pembahasan melalui media powerpoint tentang pasar. 4) Selanjutnya kolaborator menyampaikan kepada siswa bahwa pertemuan selanjutnya akan dilakukan tes hasil belajar. 5) Kolaborator menutup pertemuan dengan berdoa bersama.

\section{Pertemuan ketiga}

Pertemuan ketiga dilaksanakan hari Sabtu, 26 Oktober 2013 dengan langkah-langkah sebagai berikut. 1) Tepat pukul 07.15 peneliti bersama kolaborator memasuki ruang kelas VIII-1 dengan mengucapkan salam, mengecek keadaan siswa dan berdoa bersama. 2) Sebelum diadakan tes hasil belajar kolaborator menyampaikan kepada siswa bahwa pada saat mengerjakan tes, siswa tidak boleh bekerjasama, dan waktu yang diberikan untuk mengerjakan tes adalah 20 menit. 3) Setelah melaksanakan tes hasil belajar siswa. 4) Kolaborator menutup pertemuan dengan berdoa bersama.

\section{Observasi}

Kegiatan observasi pada siklus kedua, peneliti menemukan peningkatan keaktifan dalam melaksanakan investigasi. Secara keseluruhan siswa berperan aktif dalam menjalankan tugas masing-masing, Hal tersebut disebabkan karena masalah yang di investigasi benar-benar seperti yang mereka alami dan rasakan dalam kehidupan mereka sehari-hari. Beberapa siswa terlibat tawar menawar secara serius dengan penjual/pedagang.

Seperti halnya pada saat mepresentasekan laporan hasil investigasi di depan kelas, aktifvitas bertanya dan menanggapi pertanyaan meningkat tajam, hal tersebut dapat dilihat pada saat diskusi, hampir semua siswa mengancungkan tangan ingin menanggapi laporan investigasi kelompok penyaji. Beberapa siswa kesal karena tidak diberi kesempatan untuk menyampaikan tanggapannya. Melihat kondisi tersebut kolaborator sesekali memberikan pengertian kepada siswa bahwa mengingat waktu tidak memungkinkan kalau semua pertanyaan diaokmodir. Solusinya adalah setiap pertanyaan harus mewakili kelompok dan masing-masing kelompok diberi kesempatan untuk mengajukan satu pertanyaan.

\section{Refleksi}

Berdasarkan data hasil belajar siswa pada siklus kedua maka dapat diperoleh kesimpulan bahwa hasil Penelitian Tindakan Kelas ini sudah memenuhi kriteria keberhasilan penelitian. Hal tersebut mengacu pada nilai rata-rata kelas sebesar 78 atau angka ketuntasan belajar sebesar 90\%. Mengacu pada data hasil belajar tersebut diatas, maka pelaksanaan penelitian siklus kedua sudah 
memenuhi kriteria keberhasilan penelitian yang telah ditetapkan. Oleh karena itu, penelitian ini dihentikan sampai pada siklus kedua.

\section{Hasil Belajar Siklus Kedua}

Data hasil belajar penelitian siklus kedua diperoleh dari pelaksanaan tes uji kompetensi yang dilaksanakan pada pertemuan ketiga hari Sabtu, 26 Oktober 2013. Pelaksanaan tes uji kompetensi siklus kedua diikuti oleh 30 orang siswa dan dilaksanakan selama 20 menit. Jumlah soal yang diujikan sebanyak 20 butir dengan jenis soal obyektif pilihan ganda.

Berdasarkan hasil tes uji kompetensi yang dilakukan pada siklus kedua diperoleh nilai hasil belajar siswa dengan rincian sebagai berikut.

Tabel 2.Rincian hasil belajar siklus kedua

\begin{tabular}{llll} 
No & Rincian hasil belajar & Skor & Persentase \\
\hline 1 & Nilai rata-rata & 78.86 & - \\
2 & Tuntas & 27 & $90 \%$ \\
3 & Belum tuntas & 3 & $10 \%$ \\
\hline Ketercapaian & & Tuntas \\
\hline
\end{tabular}

Berdasarkan data tersebut rata-rata hasil belajar siswa mencapai 78.86, yang tuntas belajar 27 orang dan belum tuntas 3 orang atau hasil belajar mencapai $90 \%$.

Perbandingan Data Hasil Belajar Siswa Pada Kondisi Awal (Pra-Tindakan), Siklus I dan Siklus II

Perbandingan hasil belajar mulai dari kondisi awal (pra-tindakan), siklus pertama, dan siklus kedua maka dibawah ini disajikan tabel perbandingan sebagai berikut.

Tabel 3. Perbandingan data hasil belajar pada pra-tindakan, siklus I, dan siklus II

\begin{tabular}{|c|c|c|c|c|}
\hline No & Hasil belajar & $\begin{array}{c}\text { Kondisi } \\
\text { Awal }\end{array}$ & $\begin{array}{c}\text { Siklus } \\
\text { I }\end{array}$ & $\begin{array}{c}\text { Siklus } \\
\text { II }\end{array}$ \\
\hline 1 & Nilai rata-rata & 63.33 & 69.33 & 78.86 \\
\hline 2 & $\begin{array}{l}\text { Presentase Siswa } \\
\text { yang tuntas belajar }\end{array}$ & $20 \%$ & $40 \%$ & $90 \%$ \\
\hline 3 & $\begin{array}{l}\text { Presentase Siswa } \\
\text { yang tidak tuntas } \\
\text { belajar }\end{array}$ & $80 \%$ & $60 \%$ & $10 \%$ \\
\hline 4 & Ketercapaian & $\begin{array}{l}\text { Belum } \\
\text { Tuntas }\end{array}$ & $\begin{array}{l}\text { Belum } \\
\text { Tuntas }\end{array}$ & Tuntas \\
\hline
\end{tabular}

Berdasarkan data hasil belajar siswa tersebut, rata-rata nilai siswa pada kondisi awal hanya 63.33 atau persentase ketuntasan 20\%. Setelah diberikan tindakan pada siklus pertama ratarata hasil belajar meningkat menjadi 69.33 atau persentase ketuntasan mencapai $60 \%$, setelah diberikan tindakan pada siklus ketiga rata-rata hasil belajar mencapai 78.86 atau persentase ketuntasan meningkat menjadi $90 \%$.

Berdasarkan data hasil belajar tersebut maka penelitian pada siklus kedua ini telah sesuai dengan indikator keberhasilan penelitian yang ditetapkan yaitu $80 \%$.

\section{Perbedaan Siklus Pertama dan Siklus Kedua}

\section{Siklus Pertama}

Pelaksanaan pembelajaran pada siklus pertama mengimplementasikan langkah-langkah pendekatan CTL dikolaborasi dengan metode Group Investigation. Pendalaman materi pelajaran mennggunakan media perpustakaan dan powerpoint. Perpustakaan digunakan sebagai sarana untuk mempelajari dan menemukan jawaban permasalahan yang menjadi bahan investigasi melalui buku pelajaran, koran, majalah dan sumber-sumber yang relevan. Powerpoint digunakan sebagai sarana untuk memperjelas materi yang tidak diketemukan di perpustakaan. Seperti gambar, foto dan video yang berhubungan dengan materi. Powerpoint juga berfungsi sebagai alat untuk menjelaskan langkah-langkah CTL dan metode Group Investigation sehingga siswa lebih cepat menangkap pesan yang disampaikan. Pada siklus pertama hasil belajar siswa rata-rata 69.33 atau ketuntasan belajar mencapai $60 \%$.

\section{Siklus Kedua}

Pelaksanaan siklus kedua, peneliti memvariasi penggunaan media yaitu menggunakan media powerpoint, perustakaan, dan pasar, sebagai upaya untuk mengaitkan materi pelajaran dengan kondisi yang sebenarnya secara nyata dan dapat dirasakan oleh siswa sehingga pelajaran benar-benar kontekstual. Pasar menjadi objek observasi yang dilakukan oleh siswa untuk melakukan penelusuran tentang permasalahan yang di investigasi. Pelaksanaan observasi di pasar memberikan perubahan yang sangat besar terhadap hasil belajar pada siklus kedua. Hal ini dapat diketahui setelah dilakukan dengan tes hasil 
belajar mencapai rata-rata 78.86 atau ketuntasan belajar $90 \%$. Berdasarkan data tersebut pelasanaan siklus kedua dengan menggunakan media lingkungan (pasar) sebagai objek yang dapat diamati secara langsung (observasi) oleh siswa, sangat memberikan pengaruh yang besar terhadap hasil belajar siswa.

Pembahasan

\section{Pratindakan}

Sebelum dilaksanakan penelitian tindakan kelas, kegiatan pembelajaran yang dilaksanakan oleh guru masih menerapkan metode pembelajaran konvensional. Metode pembelajaran yang dilaksanakan cenderung berjalan satu arah (one way traffic) tanpa melibatkan secara aktif partisipasi siswa pada pembelajaran. Materi-materi yang disampaikan terkesan abstrak, teoritis, dan akademis dengan mengedepankan hafalan sebagai salah satu cara penguasaan terhadap materi yang dipelajari. Penerapan metode pembelajaran konvensional terebut mengakibatkan siswa tidak mampu mengembangkan kreativitas tidak dapat menganalisa persoalan atau masalah-masalah yang konkrit yang dihadapi dalam kehidupan sehari-hari dan hanya mampu mengingat materi yang diajarkan dalam waktu yang singkat.

Berdasarkan hal tersebut, maka peneliti bersama kolaborator melakukan penelitian tindakan kelas dengan mengimplemetasikan CTL dengan metode Group Investigation berbantuan media sebanyak dua siklus dalam 6 (enam) kali pertemuan masing-masing siklus terdiri dari 3 (tiga) kali pertemuan.

\section{Implementasi CTL dengan metode GI berban- tuan media.}

Imlementasi CTL dengan metode Group Investigation berbantuan media dilaksanakan dengan mengkolaborasi penerapan komponen CTL dengan tahapan pelaksanaan Group Investigation yang didukung oleh penggunaan media powerpoint, perpustakaan dan lingkungan sekitar (Pasar dan Koperasi sekolah) sebagai media menyampaikan informasi tentang materi pelajaran yang di investigasi agar membangun semangat, minat, motivasi belajar yang menghubungkan pelajaran secara teori dengan kehidupan nyata siswa.
Langkah-langkah Group Investigation adalah memilih topik dan membentuk kelompok, merencanakan investigasi, melaksanakan investigasi, menyusun laporan hasil investigasi, mempresentasekan laporan hasil investigasi, dan mengevaluasi hasil investigasi. Perpaduan penerapan CTL dan metode Group Investigation tersebut memberikan dampak yang signifikan terhadap kualitas pembelajaran dikelas dan peningkatan hasil belajar IPS. Sedangkan peran kolaborator dan peneliti selama proses investigasi kelompok adalah membimbing siswa dan memfasilitasi proses investigasi dan membantu menjaga aturan perilaku dalam melakukan investigasi. Pelaksanaan investigasi kelompok siswa secara aktif terlibat dalam perencanaan dan pelaksanaan investigasi dan menyajikan temuan mereka kepada teman yang lain pada saat mepresenatsekan laporan hasil investigasi.

Penggunaan media pada implementasi CTL dengan metode Group Investigasi adalah sebagai teknik untuk menyampaikan pembelajaran kepada siswa agar pelajaran IPS tidak bersifat teoritis, abstrak dan menjadi sebuah hafalan. Penggunaan media lebih kepada membuat pelajaran bermakna, menyenangkan, konkrit dan siswa benar-benar merasakan masalah-masalah yang dipelajari pada kondisi nyata yang sebenarnya. Penggunaan media pada model pembelajaran tersebut sangat berpengaruh positif kepada peningkatan minat, motivasi, dan hasil belajar siswa.

Kendala yang dihadapi dalam pelaksanaan CTL dengan metode Group Invetigation adalah a) Manajemen waktu yang belum maksimal dalam Implementasi CTL dengan metode Group Investigation (GI) berbantuan media dalam prose pembelajaran IPS, b) Pengamatan terhadap aktivitas peserta didik sangat terbatas sehingga fenomena perilaku peserta didik tidak terbaca secara menyeluruh, perubahan sikap peserta didik memerlukan pengawasan dan kontrol terus menerus, c) Pelaksanaan metode Group Investigation belum maksimal karena keterbatasan waktu, d) Kurangnya semangat kolaborator melaksanakan metode Group Investigation karena terbiasa dengan metode pembelajaran konvensional.

Peneliti mengatasi masalah pada penerapan CTL dengan metode Group Investigation dengan 
merancang dan melaksanakan pembelajaran sesuai dengan RPP yang telah disusun, meningkatkan penguasaan kelas, meningkatkan penguasaan konsep CTL, langkah-langkah pelaksanaan GI, dan penggunaan media agar kolaborator merasakan pentingnya strategi pembelajaran yang bermakna, menyenangkan, dan inovatif, pelaksanaan investigasi harus menggunakan waktu selain jam belajar disekolah.

Hasil belajar siswa setelah diterapkan CTL dengan metode GI berbantuan media.

Hasil belajar siswa setelah diterapkan strategi CTL menunjukan bahwa yang tuntas belajar pada kondisi awal sebanyak 6 orang atau sebesar $20 \%$ dari 30 orang siswa. Siklus pertama, terjadi peningkatan ketuntasan belajar menjadi 12 orang siswa atau $60 \%$ dari 30 orang siswa, sedangkan pada siklus kedua jumlah siswa yang tuntas meningkat menjadi 27 orang atau $90 \%$ dari 30 orang siswa. Berdasarkan data hasil tes belajar siswa dari pra-tindakan sampai pada sikus kedua, maka dapat disimpulkan bahwa implementasi CTL dengan metode Group Investigation berbantuan media mampu meningkatkan hasil belajar pada mata pelajaran IPS kelas VIII-1 pada SMP Negeri 6 Raha.

\section{Simpulan dan Saran}

\section{Simpulan}

Implementasi CTL dengan metode Group Investigation berbantuan media merupakan konsep strategi pembelajaran bermakna dan menyenangkan. Kolaborasi komponen CTL dengan penerapan langkah-langkah metode Group Investigation dapat meningkatkan minat dan hasil belajar siswa. Perpaduan kedua komponen tersebut siswa tidak hanya belajar melalui buku paket atau bahan ajar IPS semata, tetapi siswa juga belajar secara kooperatif dimana siswa dapat secara langsung mengaitkan materi pelajaran dengan dunia nyata siswa, sehingga siswa benar-benar merasakan secara nyata apa yang mereka pelajari. Perpaduan strategi CTL dengan langkah-langkah metode Group Investigation berdampak positif terhadap peningkatan kulaitas pembelajaran yaitu minat, sikap, keaktifan, dan hasil belajar IPS. Penggunaan media pada pembelajaran ini adalah sebagai pengantar pesan pelajaran agar siswa secara nyata melihat dan merasakan kondisi yang sebenarnya. Media yang digunakan pada penelitian ini adalah powerpoint, perpustakaan, dan alam sekitar (pasar dan koperasi sekolah).

Mengimplementasikan CTL dengan metode Group Invetigation berbantuan media ada beberapa kendala yang dihadapi yaitu: a) Manajemen waktu yang belum maksimal dalam Implementasi CTL dengan metode Group Investigation berbantuan media dalam proses pembelajaran IPS, b) Pengamatan terhadap aktivitas peserta didik sangat terbatas sehingga fenomena perilaku peserta didik tidak terbaca secara menyeluruh, perubahan sikap peserta didik memerlukan pengawasan dan kontrol terus menerus, c) Pelaksanaan metode Group Investigation belum maksimal karena keterbatasan waktu, d) Kurangnya semangat kolaborator melaksanakan metode Group Investigation karena terbiasa dengan metode pembelajaran konvensional.

Peneliti mengatasi kendala dalam mengimplementasikan CTL dengan metode Group Investigation berbantuan media pada pembelajaran IPS di kelas VIII-1 SMP Negeri 6 Raha dengan merancang dan melaksanakan pembelajaran sesuai dengan RPP yang telah disusun, meningkatkan penguasaan kelas, meningkatkan penguasaan konsep kolaborator tentang pentingnya strategi pembelajaran yang bermakna, menyenangkan, dan inovatif, pelaksanaan investigasi harus menggunakan waktu selain jam belajar disekolah.

Hasil belajar siswa menunjukan bahwa yang tuntas belajar pada kondisi awal sebanyak 6 orang atau sebesar $20 \%$ dari 30 orang siswa. Sedangkan pada siklus pertama, terjadi peningkatan ketuntasan belajar menjadi 12 orang siswa atau $60 \%$ dari 30 orang siswa, sedangkan pada siklus kedua jumlah siswa yang tuntas meningkat menjadi 27 orang atau $90 \%$ dari 30 orang siswa. Berdasarkan data hasil tes belajar siswa dari pratindakan sampai pada sikus kedua, maka dapat disimpulkan bahwa implementasi CTL dengan metode Group Investigation berbantuan media mampu meningkatkan hasil belajar pada mata pelajaran IPS kelas VIII-1 pada SMP Negeri 6 Raha. 


\section{Saran-saran}

Sebaiknya guru menerapkan pembelajaran CTL menggunakan metode Group Investigaton berbantuan media yang disesuaikan dengan materi pembelajaran. Penggunaan metode GI sangat cocok diterapkan pada pendekatan CTL agar siswa memahami masalah kehidupan seharihari. Kepada Institusi untuk dapat menerapkan pendekatan CTL dengan metode GI berbantuan media salah satu alternatif dalam kebijakan pengembangan kurikulum sekolah, khususnya pada pembelajaran IPS di SMP. Kepada peneliti lain untuk dapat mengembangkan penelitian sejenis yang mengkaji pada aspek peningkatan CTL agar dapat membantu siswa memecahkan permasalahan sehari-hari dengan konsep pembelajaran IPS.

\section{Daftar Pustaka}

Adekola, G. (2010). The impact of instructional media on thr education of youth hiv/aids in nigeria urban communities. International jurnal of scientific research in education. June 2010. Vol. 3(1), 64-72.

Anderson, L.W. \& Kratwhol, D.R. (2001). Kerangka landasan untuk pembelajaran, pengajaran, dan assesmen. (Rev. ed). (Terjemahan Agung Prihantoro). Yogyakarta: Pustaka Pelajar (Buku asli diterbitkan tahun 1956)

Arends, R.I., \& Kilcher A. (2010). Teaching for student learning: becoming an accomplished teacher. New York \& London. Routledge.

Arsyad, A. (2011). Media pembelajaran. Jakarta: Raja Grafindo Persada

Barth Jl. (1990). Method of instuction in social studies education. Boston: University Press of America.

Berns, R.G., \& Erickson,P.M (2001). Contextual teaching and learning: Preparing students foe the new economy. Colombus, $\mathrm{OH}$ : National Dissemination Center of Carrer and technical Education. Diambil pada tanggal 20 April 2013 dari http://www. ncct.com. The Highlight Zone: Re-search (a) Work.pp.1.
Ellis, A.K. (2010). Teaching and learning elementary social studies (sixth edition): Boston: Pearson Education, Inc.

Gafur, A. (2012). Desain pembelajaran: Konsep, model, dan aplikasinya dalam perencanaan pembelajaran. Yogyakarta: Ombak (Anggota IKAPI).

Gafur, A. (2003). Penerpan konsep dan prinsip pembelajaran kontekstual (CTL) dan desain pembelajaran. Cakrawala Pendidikan. Yogyakarta: UNY.

Johnson, E.B. (2002). Contextual teaching and learning. California: Corwin Press.

Kemmis, S. \& Taggart.R.Mc ( 1990). The action research planner (Third edition). Victoria: Deakin University Production Unit.

Muchith, M.S. (2008). Pembelajaran kontekstual. Semarang: RaSAIL Media Group.

Mulyatningsih. E. (2001). Riset terapan bidang pendidikan \& teknik. Yogyakarta: UNY

Orlich. et.al. (2010). Teaching strategies: Aguide to effective instruction. Boston: Arethea Thomas.

Purwanto. (2009). Evaluasi hasil belajar. Yogyakarta: Pustaka Pelajar.

Purwanto. (2011). Statistik untuk penelitian. Yogyakarta: Pustaka Pelajar.

Riyanto, Y. (2009). Paradigma baru pembelajaran. Jakarta: Kencana Prenada Media Group.

Rusman. (2011). Model-model pembelajaran mengembangkan profesionalisme guru. Jakarta: RajaGrafindo Persada.

Rusman, dkk. (2013). Pembelajaran berbasis teknologi informasi dan komunikasi. Jakarta: Raja Grafindo Persada

Scarrat, E. \& Davison, J. (2012). The media teacher's. New York: TJ International Ltd.

Scuhnk, D.H. (2012). Learning theories an educational perspective. Sixth edition. Boston: Pearson education, Inc. 
Sanjaya, W. (2008). Strategi Pembelajaran berorientasi standar proses pendidikan. Jakarta: Kencana Prenada Media Group.

Sanjaya, W. (2011). Strategi pembelajaran berorientasi standar proses pendidikan. Jakarta: Kencana Prenada Media Group.
Sanjaya, W. (2012). Perencanaan dan desain sistem pembelajaran. Jakarta: Kencana Prenada Media Group.

Sapriya. (2011). Pendidikan IPS konsep dan pembelajaran. Bandung: Remaja Rosdakarya. 